\author{
MAGDALENA SZMYTKOWSKA \\ MARIUSZ CZEPCZYŃSKI \\ Uniwersytet Gdański
}

\title{
Przemysł w mieście poprzemysłowym. Przyklad Gdyni
}

\section{ROZWÓJ POSTFORDOWSKIEJ GOSPODARKI PRODUKCYJNEJ}

Współczesny system gospodarczy przechodzi proces dynamicznych przemian, zarówno jakościowych, jak i strukturalnych. Przemysłowy model rozwoju gospodarki i miast, oparty na tradycyjnym, fordowskim czyli klasycznym modelu racjonalnie przewidywalnej konkurencji, stabilności tzw. twardych czynników rozwoju i przewidywalnym lub planowanym popycie przestał w pełni wyjaśniać zmiany zachodzące we współczesnych miastach. Nastapił spadek znaczenia nieskomplikowanych, podstawowych działań, wzrosła natomiast rola wykształcenia, w tym fachowego i zawodowego, które często wymaga długotrwałego przygotowania i praktycznej nauki (Storper 1997).

Gospodarka charakteryzuje się znacznym poziomem niepewności, co wynika z globalnego systemu ekonomicznego i skutkuje wyprowadzaniem wielu działalności i funkcji na zewnątrz firm i zlecaniem ich podwykonawcom. Prowadzi to do eksternalizacji funkcji, zarówno produkcyjnych, jak i usługowych. W postfordowskim modelu elastycznej produkcji korzyści skali produkcji, tak silnie eksponowane w modelu fordowskim i tradycyjnych teoriach lokalizacji, tracą na znaczeniu na rzecz korzyści różnorodności. To z kolei prowadzi do powstawania aglomeracji przemysłowych nowego typu - z dużą liczbą współpracujących ze sobą małych i średnich przedsiębiorstw (Stryjakiewicz 1999). Zwłaszcza przemysły zaawansowanych technologii cechują się tendencją do zlecania prac, co jednocześnie obniża ich poziom ryzyka i jest szczególnie istotne w sytuacji znacznych wahań koniunktury.

Kolejną cechą poprzemysłowej czy postfordowskiej gospodarki jest wzrost heterogeniczności działalności podmiotów gospodarczych, które w ten sposób chcą zabezpieczyć się przed zmianami koniunktury. Wzrost elastyczności działania jest osiaggany poprzez podejmowanie różnorodnych typów aktywności gospodarczej przez poszczególne podmioty. Coraz trudniej jest znaleźć firmy o wyłącznie produkcyjnym charakterze; częstokroć początkowo wyłącznie przemysłowe przedsiębiorstwa zajmują się także handlem, naprawami, transportem i innymi aktywnościami, wiele zaś zakładów, rozpoczynających swą działalność lub zajmujących się przede wszystkim usługami, dziś podejmuje także produkcję przemysłową. Sytuacja ta dotyczy w znacznej mierze małych i średnich firm, choć także 
wiele dużych przedsiębiorstw w analogiczny sposób dywersyfikuje swoją aktywność gospodarczą. Stan ten niejednokrotnie utrudnia klasyfikację branżową przedsiębiorstw i pełną analizę danych statystycznych.

Gospodarka przekształca się w nowym kierunku, o którym pisali M. Piore i C. Sabel (1984). Dotychczasowe powiązania i koncentracja hierarchiczna i horyzontalna, typowa dla wielkich koncernów i korporacji fordowskich, są zastępowane przez powiązania wertykalne i terytorialne, wynikające z regionalnej koncentracji firm. Dodatkowo także wielkie koncerny dzielą się na szereg autonomicznych podmiotów gospodarczych, „spółek-córek”, co uelastycznia powiązania, umożliwia wzrost różnorodności podejmowanych przedsięwzięć i ułatwia zarządzanie.

Przemiany gospodarcze i społeczne końca XX wieku wywierają istotny wpływ na rolę przemysłu w dynamicznie zmieniających się miastach. Następuje stopniowy spadek znaczenia produkcji przemysłowej, ale także i społecznej roli przemysłu w miastach. W latach 1960-2000 w USA udział przemysłu w PKB i zatrudnienie spadły o ponad połowę do ok. $15 \%$, produkcja przemysłowa wzrosła zaś dwukrotnie. Ceny podstawowych wyrobów przemysłowych, po uwzględnieniu inflacji, spadły o ok. $40 \%$, zaś koszty dwóch podstawowych tzw. „produktów wiedzy” - opieki zdrowotnej i edukacji - wzrosły ponad 3-krotnie ponad inflację (Drucker 2001).

Działalność przemysłowa, choć nadal pozostaje jednym z podstawowych działów gospodarki narodowej, cechuje się wyraźnie mniejszym znaczeniem w ogólnej jej strukturze. Praca w przemyśle utraciła swe prestiżowe i priorytetowe znaczenie; klasyczne czy fordowskie zakłady przemysłowe także nie pełnią już roli liderów gospodarczych miast i regionów - przekształciły się one w wielofunkcyjne grupy albo upadły.

Zmianom społecznym i organizacyjnym towarzyszą także przekształcenia branżowe przemysłu. Następuje gwałtowny rozwój nowych, opartych na wiedzy aktywności produkcyjnych, w tym informacyjnych, łącznościowych, biotechnologicznych i innych. Nowe gałęzie przemysłu cechują się różnymi czynnikami lokalizacji i rozwoju, często diametralnie innymi od klasycznych zakładów ery fordyzmu. Implikuje to zmiany przestrzenne ich lokalizacji i zmiany rynku pracy. Dodatkowo w Polsce, po odejściu od centralnie sterowanych modeli uprzemysłowienia, następują znaczne przemiany przestrzennego rozmieszczenia przedsiębiorstw, co pozostaje związane z wieloma czynnikami o charakterze społecznym i behawioralnym.

Miasto poprzemysłowe, którego gospodarka oparta jest na postfordowskich zasadach wertykalnych powiązań i eksternalizacji produkcji z dominacją usług, cechuje się przede wszystkim relatywnie niewielką i malejąca rolą przemysłu. To znaczenie przemysłu w gospodarce miasta, mierzone przede wszystkim niescjentystycznymi miarami, powoduje, że nawet przy znacznym poziomie zatrudnienia w przemyśle, jego znaczenie $\mathrm{w}$ lokalnej gospodarce może być ograniczone i miasto może nosić wyraźne cechy postindustrialne. Ta zmiana jest traktowana jako kolejny etap rozwoju cywilizacji.

Gdynia wydaje się być dobrym przykładem do analizy znaczenia przemysłu w nowoczesnym, w ogólnym znaczeniu, poprzemysłowym mieście, gdzie przemysł ten odgrywa nadal znaczną rolę w lokalnej gospodarce. 


\section{DZIAŁALNOŚĆ PRZEMYSŁOWA W GDYNI}

Rozwój przemysłu w Gdyni był wtórny wobec rozwoju portu i związanych z nim usług. Zdecydowana większość przedwojennych zakładów przemysłowych miasta związana była bądź to z produkcją spożywczą na lokalny rynek, bądź z wstępnym przetwórstwem surowców sprowadzanych drogą morską. Pewnej dynamiki nabrał przemysł w Gdyni we wczesnych latach 40. ubiegłego wieku, gdy miasto stało się jedną z głównych baz niemieckiej marynarki wojennej, co przyczyniło się do rozwoju przemysłu stoczniowego i elektromaszynowego, skierowanego na produkcję wojskową. Wraz z intensywną industrializacją kraju po drugiej wojnie światowej, powstawały nowe zakłady przemysłowe oraz rozbudowywano istniejące w Gdyni fabryki. Większość zakładów produkcyjnych miasta związana była $\mathrm{z}$ podstawową działalnością przeładunkową, wykorzystując czynnik aglomeracji produkcji, rynku zbytu i dogodnych warunków transportowych. Niemal cała działalność przemysłowa miasta była skupiona w dzielnicy portowo-przemysłowej.

Wraz ze zmianą systemu politycznego i gospodarczego kraju po 1989 roku zmieniły się uwarunkowania rozwoju działalności przemysłowej, co przyczyniło się do systematycznych przemian struktury tej gałęzi gospodarki w mieście. Przemysł Gdyni w nowych warunkach ekonomicznych nadal zachowuje swą istotną pozycję, przede wszystkim ze względu na rolę największego i dominującego pracodawcy w mieście - Stoczni Gdyńskiej. Udział przemysłu w strukturze gospodarczej miasta został przedstawiony poprzez strukturę zatrudnienia (ryc. 1). Zmiany organizacyjne i strukturalne gospodarki Polski lat 90. przyczyniły się do spadku zatrudnienia w tradycyjnych działach, jak przemysł czy transport, nastappił natomiast rozwój sektorów skierowanych na obsługę ludności, w tym handlu, obsługi nieruchomości i firm, edukacji i ochrony zdrowia.

\begin{tabular}{|c|c|c|c|c|c|c|c|c|c|c|c|c|c|}
\hline \multicolumn{14}{|l|}{$35 \%$} \\
\hline $30 \%$ & & & & & & & & & & & & & \\
\hline $25 \%$ & & & & & & & & & & & & & \\
\hline $20 \%$ & & & & & & & & & & & & & \\
\hline $15 \%$ & & & & & & & & & & & & & \\
\hline & & & & & & & & & & & & & \\
\hline & & & & & & & & & & & & & \\
\hline $5 \%$ & & & & & & & & 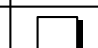 & $\square$ & $\square$ & + & $\square$ & \\
\hline & 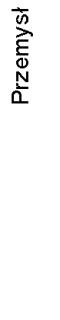 & 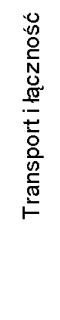 & 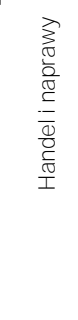 & 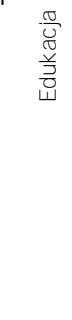 & 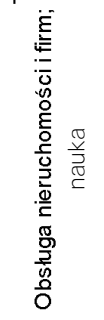 & 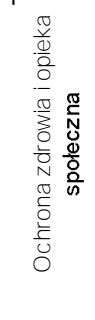 & 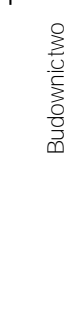 & 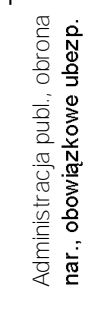 & 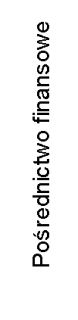 & 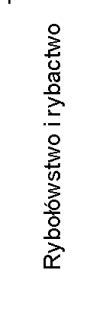 & 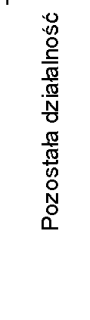 & 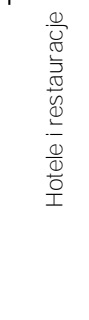 & 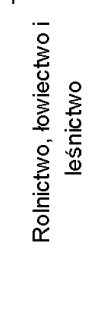 \\
\hline
\end{tabular}

Ryc. 1. Struktura zatrudnienia w Gdyni wg sekcji EKD w 2001 roku 
W 2001 roku w Gdyni najwięcej osób (prawie 21 tys., co stanowi 29\% ogółu pracujących) zatrudniają przedsiębiorstwa o charakterze produkcyjnym, natomiast piąta część ogółu pracuje w handlu i naprawach. Te dwa działy skupiają niemal połowę zatrudnionych w Gdyni osób. W kolejnych sekcjach: obsłudze nieruchomości i firm, budownictwie, transporcie i łączności, ochronie zdrowia i edukacji pracuje około 40\%. Relatywnie wysoka pozycja przemysłu w strukturze gospodarki miasta wiąże się $\mathrm{z}$ wieloletnią dominacją sektora portowo-przemysłowego oraz ze strukturą zakładów przemysłowych.

Zatrudnienie w przemyśle według wybranych działów przedstawia ryc. 2. Zauważalna jest wyraźna i zdecydowana dominacja najważniejszego w Gdyni działu - budowa i naprawy statków, gdzie pracuje ponad 13 tys. osób, stanowiących ponad dwie trzecie pracujących w przemyśle. Dział ten praktycznie ogranicza się do Stoczni Gdynia oraz dwóch stoczni remontowych: Marynarki Wojennej i Nauta. Produkcja artykułów spożywczych i zaopatrzenie w media to kolejne działy, o zdecydowanie mniejszym udziale niż stocznie (odpowiednio 8,4 i 6,4\%). Pozostałe działy, w tym produkcja odzieży, wyrobów z metali, maszyn i urządzeń oraz przetwórstwo rybne, zatrudniają od 3 do $4 \%$ ogółu pracujących w przemyśle w Gdyni i mają obecnie marginalne znaczenie w strukturze zatrudnienia i produkcji.

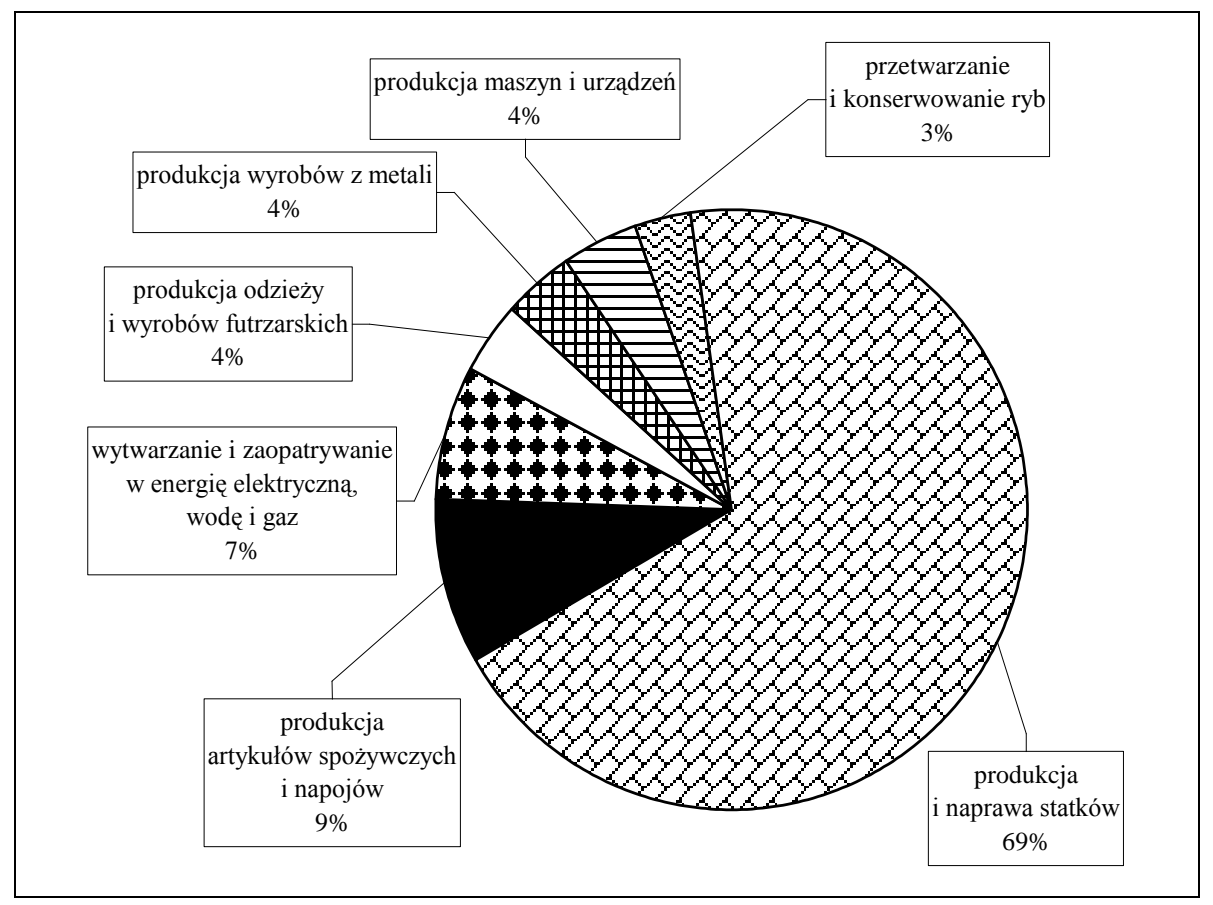

Ryc. 2. Struktura przemysłu w Gdyni wg zatrudnienia w działach w 2001 roku

Źródło: opracowanie własne na podstawie: Rocznik Statystyczny Gdyni 2001, US Gdańsk

Należy także zwrócić uwagę na względną stabilizację zatrudnienia w przemyśle w latach transformacji społeczno-gospodarczej, które w minionym dziesięcioleciu wahało się między 28 a $30 \%$. 
PRZESTRZENNE I ORGANIZACYJNE PRZEKSZTAŁCENIA PRZEMYSŁU W MIEŚCIE

Działalność przemysłowa w Gdyni, podobnie jak w większości innych miast portowych, cechuje się znaczną koncentracją przestrzenną. Zdecydowana większość produkcji, zatrudnienia i zakładów zlokalizowana jest w dzielnicy portowo-przemysłowej, otaczającej basen portowy i przylegającej od północy do śródmieścia (ryc. 3).

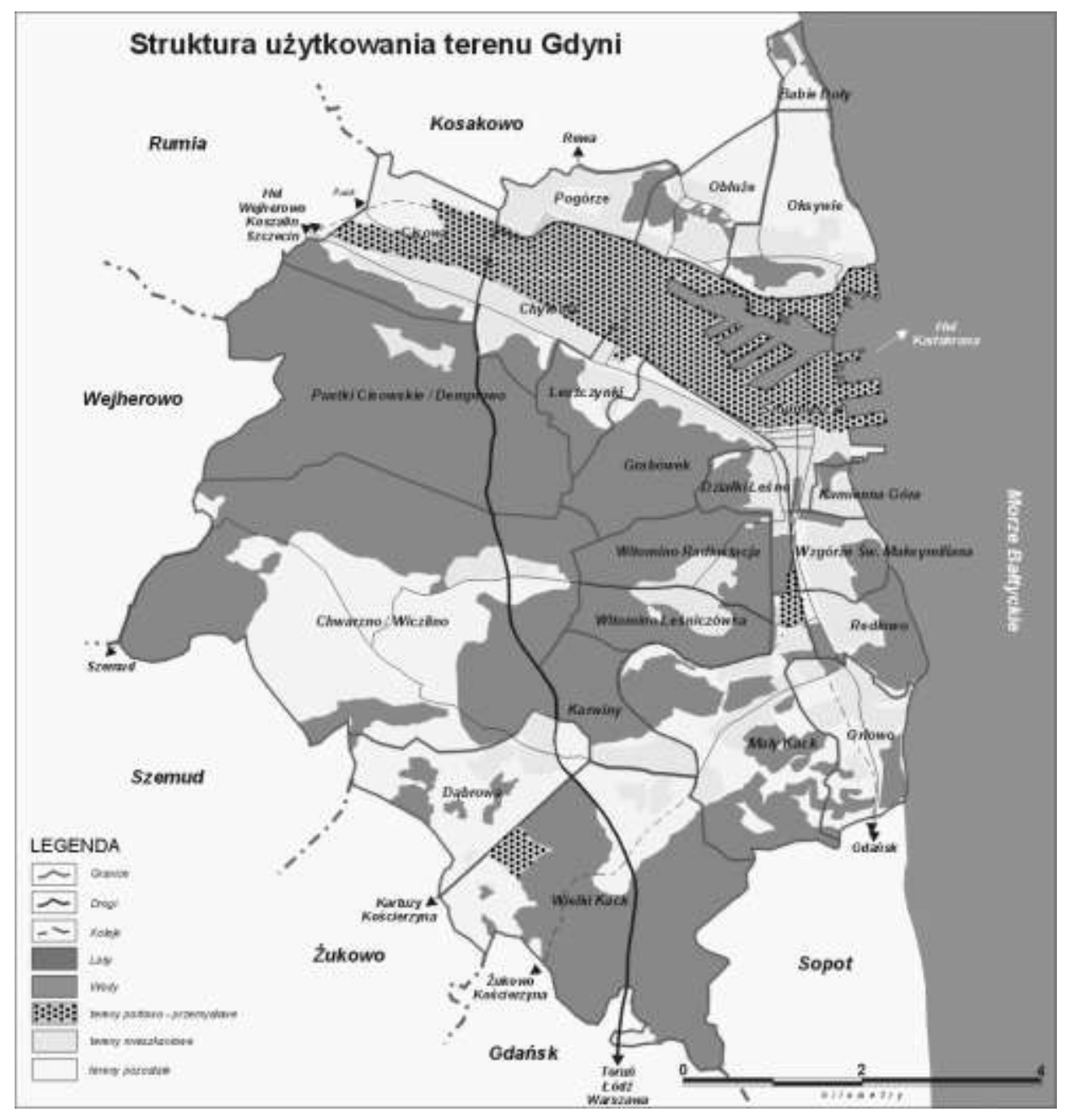

Ryc. 3. Lokalizacja działalności przemysłowej w Gdyni w 2001 roku

Niemal wszystkie duże i średnie przedsiębiorstwa produkcyjne, a także znaczna liczba małych firm skoncentrowana jest wokolicach ulic Hutniczej, Janka Wiśniewskiego, Kwiatkowskiego i Puckiej. Obszar ten, wraz z przylegającymi terenami portowymi oraz 
bazą Marynarki Wojennej, stanowi zwartą przestrzennie dzielnicę o dominujących funkcjach przeładunkowo-produkcyjnych.

Produkcja przemysłowa rozwijała się także w Gdyni w dwóch innych obszarach. Od lat 40. ubiegłego wieku zakłady przemysłowe lokalizowano także w Redłowie, w pobliżu głównej arterii komunikacyjnej miasta, przy drodze do Gdańska. Tzw. Redłowo Przemysłowe, $\mathrm{z}$ uwagi na dogodne położenie i rozbudowę systemu drogowego, przestało obecnie niemal zupełnie pełnić funkcje produkcyjne, z uwagi na wyparcie ich przez biura i inne usługi.

Najnowszą dzielnicą przemysłową miasta jest Chwaszczyno, w pobliżu zachodniej granicy Gdyni, której rozwój rozpoczął się po przeniesieniu tam w latach 80. fabryki farb z Gdańska Oliwy. Obecnie, przy dostępie do zainwestowanych terenów, tam właśnie powstają nowo lokowane w Gdyni zakłady produkcyjne różnych branż.

Procesy zmian własnościowych i organizacyjnych w przedsiębiorstwach przemysłowych w Gdyni przebiegały w zbliżony sposób jak w innych miastach kraju. Ścieżki przekształceń największych z nich wyglądają bardzo podobnie: państwowe przedsiębiorstwa na początku lat 90 . uległy restrukturyzacji, w wyniku czego powstały spółki akcyjne, będące zazwyczaj jednoosobowymi spółkami skarbu państwa. Mniejsze przedsiębiorstwa natomiast bądź to uległy likwidacji, bądź zostały w całości przejęte przez firmy prywatne.

Wszystkie duże firmy przemysłowe Gdyni, w tym Stoczni Gdynia, z jednej strony podjęły działania zmierzające do eksternalizacji produkcji i wyprowadzania poszczególnych zadań operacyjnych poza strukturę firmy, z drugiej natomiast uelastyczniły strukturalną organizację, poprzez wydzielenie szeregu wyspecjalizowanych spółek-córek, zajmujących się poszczególnymi etapami produkcji lub usług. Zdywersyfikowane profile działalności, nie tylko przemysłowej, odpowiadają potrzebie tworzenia wertykalnych powiązań organizacyjnych, wydatnie ułatwiających funkcjonowanie przedsiębiorstw w zmieniających się warunkach gospodarczych.

\section{ZNACZENIE PRZEMYSŁU W GOSPODARCE GDYNI}

Rolę i znaczenie przemysłu w mieście oddaje pozycja przedsiębiorstw przemysłowych w rankingu największych gdyńskich firm (tab. 1). Zdecydowany prym wśród lokalnych przedsiębiorstw wiedzie Stocznia Gdynia S.A., zatrudniająca niemal połowę wszystkich pracujących w przemyśle w mieście oraz 12\% ogółu pracujących w Gdyni. Przewaga stoczni, choć nie tak wyraźna, występuje także w przychodach z działalności, 3-krotnie wyższych niż następnej w rankingu spółki. Stocznia Gdynia S.A. jest największą stocznią w Europie, posiadająca w ramach Grupy Stoczni Gdynia udziały w Stoczni Gdańskiej oraz wielu innych przedsiębiorstwach ${ }^{\mathbf{1}}$. Stocznię Gdynia, będącą obecnie spółką z dominującymi udziałami pracowników i zarządu, czekają dalsze przekształcenia własnościowe i organizacyjne.

\footnotetext{
${ }^{1}$ Obecna sytuacja finansowa Grupy Stoczni Gdynia i brak stabilnych perspektyw dalszego funkcjonowania może przyczynić się do zachwiania całej gospodarki miasta i regionu.
} 
Tabela 1. Największe przedsiębiorstwa w Gdyni ${ }^{2}$ według liczby zatrudnionych (pow. 250 osób) w 2001 roku

\begin{tabular}{|c|c|c|c|}
\hline Lp. & Przedsiębiorstwo & $\begin{array}{c}\begin{array}{c}\text { Pracu- } \\
\text { jący }\end{array} \\
\end{array}$ & Sektor \\
\hline 1. & Stocznia Gdynia S.A. & 8921 & przemysł \\
\hline 2. & Stocznia Marynarki Wojennej & 3000 & przemysł \\
\hline 3. & Zarząd Morskiego Portu Gdynia S.A. & 2574 & transport \\
\hline 4. & Stocznia Remontowa „Nauta” S.A. & 1795 & przemysł \\
\hline 5. & Prokom Software S.A. & 1477 & handel i usługi \\
\hline 6. & BTDG - Bałtycki Terminal Drobnicowy Gdynia sp. z o.o. & 1200 & transport \\
\hline 7. & Przedsiębiorstwo Połowów, Przetwórstwa i Handlu „Dalmor” S.A. & 1052 & przemysł \\
\hline 8. & Okręgowe Przedsiębiorstwo Energetyki Cieplnej sp. z o.o. & 962 & przemysł \\
\hline 9. & Zakłady Radiowe „Radmor” S.A. & 800 & przemysł \\
\hline 10. & Wilbo S.A. & 750 & przemysł \\
\hline 11. & MG Probud S.A. & 663 & budownictwo \\
\hline 12. & „Euromal - Grupa Stoczni Gdynia” Spółka Kapitałowa & 630 & przemysł \\
\hline 13. & Przedsiębiorstwo Wodociagów i Kanalizacji sp. z o.o. & 560 & przemysł \\
\hline 14. & MTMG - Morski Terminal Masowy Gdynia sp. z o.o. & 547 & transport \\
\hline 15. & BCT - Bałtycki Terminal Kontenerowy sp. z o.o. & 530 & transport \\
\hline 16. & $\begin{array}{l}\text { WUŻ - Przedsiębiorstwo Usług Żeglugowych i Portowych } \\
\text { Gdynia sp. z o.o. }\end{array}$ & 460 & transport \\
\hline 17. & Zakłady Odzieżowe „Wybrzeże” Spółdzielnia Inwalidów & 453 & przemysł \\
\hline 18. & „Energomontaż-Północ” S.A. oddział w Gdyni & 412 & budownictwo \\
\hline 19. & Portowy Zakład Techniczny sp. z o.o. & 400 & transport \\
\hline 20. & „Prokom Investments” S.A. & 400 & handel i usługi \\
\hline 21. & Przedsiębiorstwo Handlu Zagranicznego „Baltona” S.A. w Gdyni & 400 & handel i usługi \\
\hline 22. & $\begin{array}{l}\text { Zakłady Urządzeń Chłodniczych i Klimatyzacyjnych „Klimor” } \\
\text { sp. z o.o. }\end{array}$ & 362 & przemysł \\
\hline 23. & Nordea Bank Polska S.A. & 361 & handel i usługi \\
\hline 24. & $\begin{array}{l}\text { Przeds. Wielobranżowe Energetyczno-Budowlane „MEGA” } \\
\text { Szulist Jerzy }\end{array}$ & 340 & przemysł \\
\hline 25. & „Pol-Supply” sp. z o.o. & 330 & transport \\
\hline 26. & Hossa S.A. & 318 & budownictwo \\
\hline 27. & Spółdzielnia Niewidomych „Sinema” & 315 & przemysł \\
\hline 28. & Powszechna Kasa Oszczędności Bank Polski S.A. & 311 & handel i usługi \\
\hline 29. & „Elektrim-Energoblok-Gdynia” S.A. & 300 & handel i usługi \\
\hline 30. & Przedsiębiorstwo Budowy Urządzeń Chłodniczych S.A. & 300 & przemysł \\
\hline 31. & C. Hartwig Gdynia S.A. & 298 & transport \\
\hline 32. & „Orbis” S.A. Oddział Hotel „Gdynia” & 287 & handel i usługi \\
\hline 33. & Bank Współpracy Europejskiej S.A. Oddział w Gdyni & 275 & handel i usługi \\
\hline 34. & „BIG Bank Gdański” S.A. I Oddział w Gdyni & 253 & handel i usługi \\
\hline 35. & Bałtycki Terminal Zbożowy sp. z o.o. & 250 & transport \\
\hline 36. & Portowy Zakład Transportu „Trans-Port” sp. z o.o. & 250 & transport \\
\hline 37. & Timoro sp. z o.o. & 250 & przemysł \\
\hline
\end{tabular}

Źródło: opracowanie własne

\footnotetext{
${ }^{2}$ Bez instytucji publicznych (administracja publiczna, ochrona zdrowia, edukacja itp.) i PKP.
} 
Kolejne pozycje w rankingu największych firm w mieście zajmuje państwowa Stocznia Marynarki Wojennej, na kolejnych miejscach są Zarząd Morskiego Portu Gdynia, Stocznia Remontowa „Nauta” i Prokom Software. Z piątki największych firm trzy mają charakter przemysłowy i zatrudniają niemal 14 tys. osób. Powyższe zestawienie wyraźnie podkreśla rangę zakładów produkcyjnych w gospodarce lokalnej; wśród 37 największych firm jest 15 przedsiębiorstw przemysłowych, 10 firm transportowych (funkcje portowoprzeładunkowe), 9 handlowo-usługowych oraz 3 budowlane.

Tabela 2. Podstawowe profile działalności w największych przedsiębiorstwach przemysłowych w Gdyni w 2002 roku

\begin{tabular}{|c|c|}
\hline PRZEDSIĘBIORSTWA PRZEMYSŁOWE & PROFILE DZIAŁALNOŚCI \\
\hline Stocznia Gdynia S.A. & budowa i naprawy statków \\
\hline Stocznia Marynarki Wojennej & budowa i naprawy statków \\
\hline Stocznia Remontowa „Nauta” S.A. & budowa i naprawy statków \\
\hline $\begin{array}{l}\text { Przedsiębiorstwo Połowów, Przetwórstwa i Handlu } \\
\text { „Dalmor” S.A. }\end{array}$ & rybołówstwo w wodach morskich \\
\hline Okręgowe Przedsiębiorstwo Energetyki Cieplnej sp. z o.o. & $\begin{array}{l}\text { zaopatrzenie w energię elektryczną, } \\
\text { wodę i gaz }\end{array}$ \\
\hline Zakłady Radiowe „Radmor” S.A. & $\begin{array}{l}\text { prod. sprzętu i aparat. radiowej, } \\
\text { telewiz. i telekom. }\end{array}$ \\
\hline Zakłady Przetwórstwa Rybnego „Wilbo” S.A. & $\begin{array}{l}\text { produkcja artykułów spożywczych } \\
\text { i napojów }\end{array}$ \\
\hline Euromal - Grupa Stoczni Gdynia & budowa i naprawy statków \\
\hline Przedsiębiorstwo Wodociągów i Kanalizacji sp. z o.o. & $\begin{array}{l}\text { zaopatrzenie w energię elektryczną, } \\
\text { wodę i gaz }\end{array}$ \\
\hline Zakłady Odzieżowe „Wybrzeże” Spółdzielnia Inwalidów & produkcja odzieży \\
\hline $\begin{array}{l}\text { Zakłady Urządzeń Chłodniczych i Klimatyzacyjnych } \\
\text { „Klimor” sp. z o.o. }\end{array}$ & produkcja maszyn i urządzeń \\
\hline Spółdzielnia Niewidomych „Sinema” & $\begin{array}{l}\text { produkcja maszyn i aparatury elek- } \\
\text { trycznej }\end{array}$ \\
\hline Przedsiębiorstwo Budowy Urządzeń Chłodniczych S.A. & produkcja maszyn i urządzeń \\
\hline Timoro sp. z o.o. & budowa i naprawy statków \\
\hline
\end{tabular}

Źródło: opracowanie własne

Poza tradycyjnymi w mieście profilami działalności, jak budowa i naprawa statków, przetwórstwo ryb i zaopatrzenie w media, rozwijają się nowe typy działalności, jak produkcja chemikaliów, wyrobów z tworzyw sztucznych, odzieży ${ }^{3}$, żywności i napojów, maszyn i urządzeń oraz instrumentów precyzyjnych.

Wiele $\mathrm{z}$ tych firm, poza działalnością produkcyjną, zajmuje się także usługami, zwłaszcza handlem i naprawami. Stwarza to poważne trudności w ich identyfikacji branżowej i odróżnieniu firm przemysłowych od usługowych. Szczególnie istotna wydaje się

${ }^{3} \mathrm{~W}$ Gdyni znajduje się np. duża fabryka odzieży sportowej znanej polskiej firmy produkującej pod marką Fjord Nansen. 
być ta kwestia w przypadku Gdyni, gdzie niemal wszystkie przedsiębiorstwa, identyfikowane jako przemysłowe, prowadzą szereg innych pozaprzemysłowych (poprzemysłowych) aktywności, począwszy od usług związanych ze sprzedażą i marketingiem produktów, poprzez pełny serwis oferowanych produktów, na działalności obsługowej wobec innych firm (wynajem własnych gruntów i powierzchni biurowych) kończąc. Poza przytoczonym już wcześniej przykładem Stoczni Gdynia, warto także wskazać na charakterystyczną kilkutorową działalność gospodarczą prowadzoną przez spółkę Dalmor. Podstawowym profilem działalności tej firmy jest rybołówstwo dalekomorskie oraz przetwórstwo rybne. Procesy restrukturyzacji zachodzące $\mathrm{w}$ firmie, dążenia do obniżania kosztów funkcjonowania spółki oraz splot niekorzystnych czynników zewnętrznych (m.in. blokowanie przez stronę rosyjską połowów na Morzu Ochockim) spowodowały, że w obecnej sytuacji niezmiernie ważną aktywnością gospodarczą firmy, umożliwiającą jej dalsze funkcjonowanie jest obsługa nieruchomości i firm w zakresie wynajmu bądź sprzedaży atrakcyjnych gruntów na obszarze portu gdyńskiego oraz powierzchni biurowych, stanowiących majątek spółki.

Jednocześnie należy zaznaczyć, iż nie mniejszych trudności w badaniach przysparza identyfikacja działalności produkcyjnej w firmach z założenia nieprzemysłowych, zakwalifikowanych do innych sekcji EKD. Przykładem są tu firmy z branży budowlanej, które oprócz podstawowego profilu działalności, tzn. realizacji różnego rodzaju inwestycji budowlanych, podejmują produkcję materiałów budowlanych na skalę przemysłową.

\section{PRZYSZŁOŚĆ PRZEMYSŁU W GDYNI}

Z analizy dokumentów strategicznych miasta Gdyni jednoznacznie wynika, iż dla dalszego dynamicznego rozwoju gospodarki lokalnej niezbędne jest „dążenie do uniezależnienia kondycji gospodarczej miasta od przedsiębiorstw sektora morskiego", które cechuje nadmierna wrażliwość na wahania koniunktury w handlu zagranicznym (przemysł stoczniowy), zbytnie uzależnienie od czynników zewnętrznych (Dalmor - blokowanie połowów wakwenach dalekomorskich) oraz często nierozwiązane kwestie własnościowe i restrukturyzacyjne. Wskazuje się zatem na konieczność rozszerzenia zakresu działalności przedsiębiorstw morskich poprzez:

$\checkmark$ inwestowanie w przedsięwzięcia na lądzie, mające na celu zwiększenie produkcji i usług tworzących tzw. wartość dodaną (np. parki technologiczne);

$\checkmark$ rozwój usług dystrybucyjno-logistycznych w miejsce tradycyjnej wytwórczości przemysłowej w porcie;

$\checkmark$ wdrażanie wysokich technologii w procesach produkcyjnych, zwiększających konkurencyjność gdyńskiej gospodarki.

Ponadto wskazuje się na konieczność wspierania sektora małych i średnich przedsiębiorstw, których elastyczność organizacji pracy i produkcji zdecydowanie podnosi konkurencyjność firmy na rynku. Szczególnie istotne jest aktywizowanie przedsiębiorczości w Gdyni poprzez „tworzenie systemu współdziałania podmiotów gospodarczych, umożliwiających wchodzenie małych i średnich firm gdyńskich w sieci kooperacyjne, wspieranie powiązań między nauką, badaniami i rozwojem a działalnością gospodarczą" oraz pod- 
trzymanie pozytywnego trendu rozwoju sieci otoczenia biznesu, które znalazły sprzyjający klimat dla swego funkcjonowania.

Duży nacisk kładzie się również na rozwój sektora high-tech oraz finansowego. W Gdyni funkcjonują, oprócz największej polskiej spółki informatycznej Prokom Software S.A., dziesiątki firm z sektora małych i średnich przedsiębiorstw, które zapoczątkowały tworzenie się środowiska innowacyjnego Gdyni. Mają być ważnym ogniwem w rozpoczynającym swą działalność Parku Technologicznym oraz Centrum Nowych Technologii instytucjach pełniących rolę łącznika między środowiskiem naukowym i sektorem IT a podmiotami gospodarczymi. Współpraca tychże podmiotów jest warunkiem konkurencyjności gospodarki lokalnej.

\section{Literatura}

Drucker P., 2001, The next society, „The Economist”, 15.08, Londyn Piore M., Sabel C., 1984, The Second Industrial Divide, New York

Storper M., 1997, The Regional World: Territorial Development in a Global Economy, New York

Stryjakiewicz T., 1999, Adaptacja przestrzenna przemystu $w$ Polsce $w$ warunkach transformacji, Poznań

Materiały informacyjne i statystyczne Biura Planowania Rozwoju Miasta Urzędu Miasta Gdyni

Rocznik Statystyczny Miasta Gdyni 2001, Urząd Statystyczny, Gdańsk

Strategia Rozwoju Gdyni, 1998, Urząd Miasta Gdyni

Gdynia Strategiczna 2013, 2002, maszynopis, Urząd Miasta Gdyni 